\title{
Effect of anionic salts in concentrate mixture on some blood and urine minerals, acid-base balance and feed intake of dry pregnant cows on grass silage based feeding with high calcium intake
}

\author{
Susanna Tauriainen \\ Department of Animal Science, PO Box 28, FIN-00014 University of Helsinki, Finland, \\ e-mail: susanna.tauriainen@seamk.fi \\ Satu Sankari \\ University of Helsinki, Department of Clinical Veterinary Sciences, Hämeentie 57, PO Box 6, \\ FIN-00581 Helsinki, Finland \\ Liisa Syrjälä-Qvist \\ Department of Animal Science, PO Box 28, FIN-00014 University of Helsinki, Finland
}

\begin{abstract}
The objective was to study the effects of anionic salts in a concentrate mixture on some blood and urine minerals, acid-base balance and intake of Ayrshire cows fed a grass silage based diet. Eighteen nonlactating, pregnant Ayrshire cows were divided randomly into two groups according to their expected calving date. Dietary cation-anion balance (DCAB), calculated as milliequivalents $\left[\left(\mathrm{Na}^{+}+\right.\right.$ $\left.\left.\mathrm{K}^{+}\right)-\left(\mathrm{Cl}^{-}+\mathrm{S}^{2-}\right)\right]$ of the two diets was $+410 \mathrm{mEq} / \mathrm{kg}$ of dietary dry matter (DM) in the high DCAB group and $+81 \mathrm{mEq} / \mathrm{kg}$ of the dietary DM in the low DCAB group, respectively. The DCAB was formulated using $\mathrm{NH}_{4} \mathrm{Cl},\left(\mathrm{NH}_{4}\right)_{2} \mathrm{SO}_{4}$ and $\mathrm{MgCl}_{2}$ as anionic salts. Cows received grass silage $(5.2 \mathrm{~kg}$ $\mathrm{DM})$, hay $(0.8 \mathrm{~kg} \mathrm{DM})$ and a concentrate mixture $(1.7 \mathrm{~kg} \mathrm{DM})$ until calving. Both diets were supplemented with $100 \mathrm{~g} \mathrm{CaCO}_{3}$ to achieve a high $\mathrm{Ca}$ intake $(82 \mathrm{~g} \mathrm{Ca} / \mathrm{d})$. Blood and urine samples were collected 4, 3, 2 and 1 week before the expected calving date, at calving, the day after calving and 1 week following calving. Current data indicated that it may be difficult to formulate a diet with a negative $\mathrm{DCAB}$, if the $\mathrm{K}$ content of grass silage is over $30 \mathrm{~g} / \mathrm{kg} \mathrm{DM}$. As a result, no increase in blood $\mathrm{Ca}^{2+}$ and a relatively high urinary $\mathrm{pH}$ were observed. Furthermore, it may advantageous to increase $\mathrm{Mg}$ intakes above current Finnish recommendations when dietary Ca concentrations are high, since $28 \%$ of experimental cows experienced hypomagnaesemia at parturition.
\end{abstract}

Keywords: calcium, cation-anion balance, cows, magnesium, minerals, palatability

\section{Introduction}

The level of dietary cation-anion balance (DCAB) has been manipulated in dairy cow stud- ies using anionic salts (mineral salts high in $\mathrm{Cl}$ or $\mathrm{S}$ relative to $\mathrm{Na}$ and $\mathrm{K}$ ) during the dry period. An increase in blood calcium $(\mathrm{Ca})$ ion concentrations at calving have been reported at $\mathrm{DCAB}$ levels of $-8 \mathrm{mEq} / \mathrm{kg}$ dry matter (DM) (Phillippo 
Tauriainen, S. et al. Effect of anionic salts on dry cows III

et al. 1994), $-35 \mathrm{mEq} / \mathrm{kg}$ DM (Abu Damir et al. 1994) or $-75 \mathrm{mEq} / \mathrm{kg} \mathrm{DM}$ (Oetzel et al. 1988). However, a decrease in DCAB did not change total $\mathrm{Ca}$ concentration in plasma when DCAB was $-8 \mathrm{mEq} / \mathrm{kg}$ DM (Phillippo et al. 1994, Romo et al. 1991). Although a change in total Ca concentration in plasma was noticed with $-30 \mathrm{mEq} /$ $\mathrm{kg}$ DM in DCAB, a lack of the prophylactic effect on the occurrence of milk fever has been documented (Tucker et al. 1992).

In contrast, DCAB as low as $-428 \mathrm{mE} / \mathrm{kg} \mathrm{DM}$ (Wang and Beede 1992) has been observed to induce a metabolic acidosis. Furthermore, in a recent study (Tauriainen et al. 1998a) five cows from ten had a metabolic acidosis after one week from the start of the trial when DCAB was -247 $\mathrm{mEq} / \mathrm{kg}$ DM. Anionic salts in the concentrate mixture must be carefully formulated to achieve sufficient effects but to avoid excessive acidification. Therefore, before widescale application can be recommended for grass silage based diets, safe but effective dietary concentrations of anionic salts should be established.

The primary objective of the present study was to determine if anionic salts have an effect on some blood and urine parameters when DCAB and $\mathrm{Ca}$ intake were moderately high on a grass silage based diet. In nearly all studies with a low DCAB, anionic salts were offered in loose form. In practice however, this would place further demands on the producer, and therefore the current study attempted to evaluate the potential and suitability of concentrate inclusion of anionic salts for cows fed grass silage based diet.

\section{Material and methods}

\section{Experimental design and treatments}

Ten Ayrshire cows (age $42 \pm 7$ months) and eight heifers (age $24 \pm 1$ months) were selected from the University of Helsinki research farm. Cows weighed $588 \pm 39 \mathrm{~kg}$ at the beginning of the trial and they were randomly assigned to two dietary treatment groups with 5 cows and 4 heifers per diet. Animals received grass silage (5.2 kg DM/ d), hay $(0.8 \mathrm{~kg} \mathrm{DM} / \mathrm{d})$ and an experimental concentrate mixture $(1.7 \mathrm{~kg} \mathrm{DM} / \mathrm{d})$. In addition, experimental cows were given vitamin and selenium supplementation once a week as follows: vitamin A 200000 IU/cow/week, vitamin D 40 $000 \mathrm{IU} / \mathrm{cow} /$ week, vitamin E $400 \mathrm{mg} / \mathrm{cow} / \mathrm{wk}$ and selenium $2 \mathrm{mg} / \mathrm{cow} /$ week. The feeding period started 4 weeks before the expected calving date and ended at parturition. Immediately after parturition, cows entered the normal nutrition and management program applied at the University of Helsinki research farm.

Experimental diets were: Diet 1; high DCAB (control), Diet 2; low DCAB. Cows were divided into two blocks according to age. Within each block cows were randomly assigned to two treatments in groups of two animals according to expected calving date. The low DCAB diet contained added chloride $(\mathrm{Cl})$ and sulphur $(\mathrm{S})$, supplied primarily by adding chlorides of ammonium and magnesium and ammonium sulphate. A mixture of different salts was used to avoid potential toxicity of using only one acidifying salt. Anionic salts were included in the concentrate mixture which was pelletted. Chemical composition of the experimental diets is shown in Table 1 . The composition of concentrate mixtures has been reported previously (Tauriainen et al. 1998a). Using the formula $\left[\left(\mathrm{Na}^{+}+\mathrm{K}^{+}\right)-\left(\mathrm{Cl}^{-}+\right.\right.$ $\left.\mathrm{S}^{2-}\right)$ ], the high DCAB diet contained $+410 \mathrm{mEq} /$ $\mathrm{kg}$ DM, and the low DCAB diet contained +81 $\mathrm{mEq} / \mathrm{kg}$ DM. Sulphur was included to avoid an excessive $\mathrm{Cl}$ content. Tucker et al. (1991) have also demonstrated that the effect of $S$ on systemic acid-base status in lactating cows is similar to the effect of $\mathrm{Cl}$. The high $\mathrm{Ca}$ level was achieved by adding $100 \mathrm{~g} / \mathrm{d}$ calcium carbonate to the ration. The $\mathrm{Ca}$ supplement was used because we wanted to simulate Finnish situations, particularly in the South, where the high calcium content of the grass silage can compromise the mineral metabolism of dry cows. The energy content of the diet expressed as feed units (1 $\mathrm{FU}=1 \mathrm{~kg}$ barley with 11.7 MJ metabolizable energy calculated according to MAFF 1975) was 
Vol. 7 (1998): 545-552.

Table 1. Formulation of experimental diets ${ }^{1)}$.

\begin{tabular}{lcc}
\hline Diet & High DCAB & Low DCAB \\
Ingredient, \% & & \\
\hline Grass silage & 66.45 & 67.44 \\
Hay & 10.32 & 10.34 \\
Concentrate mixture & 21.94 & 20.93 \\
$\mathrm{CaCO}_{3}$ & 1.29 & 1.29 \\
\hline
\end{tabular}

1) Dry matter basis.

${ }^{2)}$ Dietary cation-anion balance.

formulated to meet a moderate feed intake (i.e. 1.2 times maintenance) as recommended by van de Braak et al. (1986). Chemical analysis of the experimental diets is presented in Table 2.

Cows were housed, fed, weighed and body condition scored (Windman et al. 1982) reported previously (Tauriainen et al. 1998a). Samples of grass silage, hay and concentrate were collected and handled as documented earlier (Tauriainen et al. 1998a).

\section{Sample collection}

Blood samples were collected from the jugular vein of each cow before afternoon feeding, at 4, 3, 2 and 1 weeks prepartum, on the day of calving, and at $1 \mathrm{~d}$ and $7 \mathrm{~d}$ postpartum. Blood samples were placed on crushed ice immediately after sampling. One sample was taken into a heparinized vacuum tube for the measurements of acid-base status. Immediately after analysis of blood gases and haemoglobin of the whole blood, the remaining sample was centrifuged twice (3000 $\mathrm{g}$ for $5 \mathrm{~min}$ ) and the plasma was stored frozen for later measurements of $\mathrm{Na}, \mathrm{K}$, $\mathrm{Cl}, \mathrm{Ca}$ and $\mathrm{Mg}$. Another heparinized sample was collected into a vacuum tube for the determination of blood $\mathrm{Ca}$ ion concentration within 24 hours. The body temperature of the experimental cows was measured at each sampling.

Urine samples of each cow were collected before afternoon feeding, at 4, 3, 2, and 1 weeks prepartum, on the day of calving, and at $1 \mathrm{~d}$ and
Table 2. Dry matter intake, energy content, chemical composition $^{1)}$ and dietary cation-anion difference of the experimental diets.

\begin{tabular}{lcc}
\hline & High DCAB $^{2)}$ & Low DCAB \\
\hline $\mathrm{DMI}^{3)}, \mathrm{kg} / \mathrm{d}$ & 7.75 & 7.74 \\
$\mathrm{ME}^{4)}, \mathrm{MJ} / \mathrm{kg} \mathrm{DM}$ & 10.80 & 10.79 \\
Crude protein, \% & 14.18 & 16.58 \\
Crude fiber, \% & 24.90 & 24.96 \\
$\mathrm{ADF}^{5)}, \%$ & 28.75 & 24.84 \\
$\mathrm{NDF}^{6}, \%$ & 46.42 & 46.34 \\
$\mathrm{Ca}^{6} \%$ & 1.07 & 1.05 \\
$\mathrm{P}, \%$ & 0.47 & 0.42 \\
$\mathrm{Mg}, \%$ & 0.22 & 0.22 \\
$\mathrm{~K}, \%$ & 2.75 & 2.70 \\
$\mathrm{Na}, \%$ & 0.31 & 0.25 \\
$\mathrm{Cl}, \%$ & 1.05 & 1.70 \\
$\mathrm{~S}, \%$ & 0.21 & 0.38 \\
$\mathrm{DCAB}^{7)}, \mathrm{mEq} / \mathrm{kg} \mathrm{DM}$ & +410 & +81 \\
\hline
\end{tabular}

${ }^{1)}$ Expressed on a dry matter basis.

2) Dietary cation-anion balance.

3) Dry matter intake.

4) Metabolizable energy calculated according to MAFF (1975).

5) Acid detergent fibre.

6) Neutral detergent fibre.

7) Dietary cation-anion balance calculated as milliequivalents $\left(\mathrm{Na}^{+}+\mathrm{K}^{+}\right)-\left(\mathrm{Cl}^{-}+\mathrm{S}^{2-}\right)$ per $\mathrm{kg}$ dry matter.

7 d postpartum. Samples were obtained by manual vulval stimulation. Five $\mathrm{ml}$ of urine was pipetted into one tube contained $0.5 \mathrm{ml}$ of $12 \mathrm{~N}$ $\mathrm{HCl}$. It was frozen prior to analysis of $\mathrm{Ca}, \mathrm{Mg}$, $\mathrm{K}$ and $\mathrm{Na}$.

\section{Chemical analysis}

The $\mathrm{Cl}$ content of grass silage was determined according to AOAC (1984) procedures while other details concerning lavoratory analysis are given elsewhere (Tauriainen et al. 1998a).

\section{Statistical analysis}

The data were analysed in two parts: 1 . prepartum; from 4 weeks to 1 week before the expect- 
Tauriainen, S. et al. Effect of anionic salts on dry cows III

ed calving date. 2. peripartum; from 1 week before expected calving to 1 week after the calving. Plasma and urinary data were analysed by a repeated measures analysis of variance within the SAS (1985) general linear model procedure for a complete block design including the effects of age, DCAB and their interactions in the model. Since preliminary analysis of the raw data indicated heterogeneity of variance for $\mathrm{Na} /$ creatinine, K/creatinine, $\mathrm{OH}$-proline, $\mathrm{K} \mathrm{FE} \%$ and $\mathrm{Na} F E \%$, these variables were logarithmically transformed to achieve more homogeneous variance. A one-way analysis of variance of the four treatment groups was conducted for data collected at 4 weeks before the expected calving date to assess initial differences between experimental groups. Because of significant $(\mathrm{P}<0.05)$ differences in the ratio of $\mathrm{OH}$-proline to creatinine in the urine at the start of the trial, pre-treatment values were used as covariates for statistical analysis of $\mathrm{OH}$-proline.

\section{Results}

Cows were fed a fixed ration throughout the experiment minimising variations in feed intake. The palatability of the concentrate mixture in the low DCAB group was satisfactory, with only $0.18 \mathrm{~kg} \mathrm{DM} / \mathrm{d}$ of the concentrate mixture being refused by the low DCAB group. An average only $0.10 \mathrm{~kg} \mathrm{DM} / \mathrm{d}$ of the total DM $(7.8 \mathrm{~kg})$ was left by all cows. Body condition of all cows at parturition was satisfactory (3.4), indicating that the low feeding level (1.19 x maintenance) during the dry period had no visible adverse effects.

There were no interactions between treatment and parity for any blood or urine parameters measured. The concentration of ionised $\mathrm{Ca}$ was not affected by DCAB or parity $(\mathrm{P}>0.10)$, but it tended to be lower in cows fed a diet with low DCAB $(\mathrm{P}>0.08)$ prepartum. None of the cows showed clinical signs of milk fever around parturition. One cow in the high DCAB group had a subclinical hypocalcaemia $\left(\mathrm{Ca}^{2+}<1.00 \mathrm{mmol} /\right.$
1, Radostits et al. 1994) at parturition. Plasma $\mathrm{Na}$ was higher in the high DCAB group peripartum than the low DCAB group $(\mathrm{P}<0.05)$, but groups did not differ in plasma Na prepartum. Plasma $\mathrm{Mg}$ was not affected by treatment or parity, but four cows from the high DCAB group and one cow from the low DCAB group were shown to have hypomagnesaemia at parturition since plasma concentration of $\mathrm{Mg}$ was below $0.85 \mathrm{mmol} / \mathrm{l}$ (Samson et al. 1983). Concentrations of total $\mathrm{Ca}, \mathrm{Cl}$ or $\mathrm{K}$ in plasma were unaffected by treatments during the trial, and varied within reference ranges (Radostits et al. 1994). Blood $\mathrm{pH}, \mathrm{HCO}_{3}{ }_{3}^{-}$and base excess were not influenced by DCAB or parity throughout the experiment $(\mathrm{P}>0.10)$. Thus, all cows were acid-base balanced (Radostits et al. 1994).

Urinary calcium excretion was higher only prepartum $(\mathrm{P}<0.05$, Table 3$)$ in the low DCAB group in comparison with the high DCAB group. Urinary $\mathrm{pH}$ was much lower (prepartum $\mathrm{P}<0.01$; peripartum $\mathrm{P}<0.05$ ) in cows fed the low $D C A B$ than the high DCAB diet. Parity did not influence urinary $\mathrm{Ca}$ excretion. Treatments did not affect either urinary excretion of $\mathrm{Mg}, \mathrm{K}, \mathrm{Na}$, or urine $\mathrm{FE} \%$ of $\mathrm{Mg}, \mathrm{K}$, and $\mathrm{Na}$. Heifers tended to have lower $\mathrm{K}$ FE\% peripartum than cows $(\mathrm{P}<0.05)$. The urine $\mathrm{FE} \%$ of $\mathrm{Mg}$ and excretion of $\mathrm{Mg} /$ creatinine tended to be higher in the high DCAB group compared with the low DCAB group during the trial. Heifers excreted more $\mathrm{OH}$-proline in the urine prepartum than cows $(\mathrm{P}<0.01)$, but there was no difference between treatments throughout the experiment.

\section{Discussion}

Because of a lack of facilities only two groups of experimental cows were used. For the same reason, animal material was rather young for the study of calcium metabolism. Since acid base balance can be evaluated regardless of age (Phillips 1970), heifers were included in the current study. 
Vol. 7 (1998): 545-552.

Table 3. Effect of dietary cation-anion balance (DCAB) and Ca intake on mean plasma mineral concentrations and urinary Ca excretion.

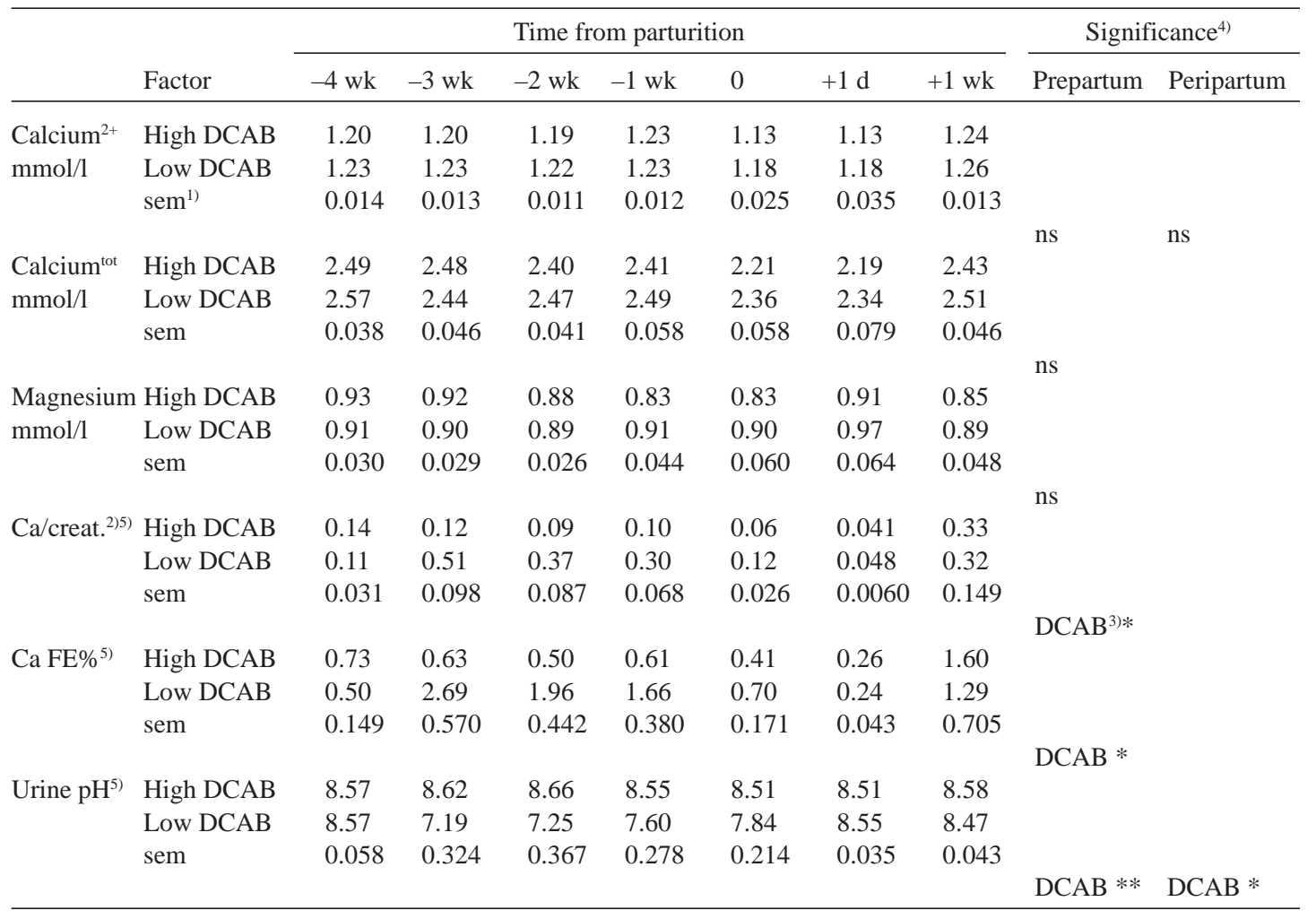

1) $\mathrm{sem}=$ standard error of means

2) $\mathrm{Ca}$ /creatinine, $\mathrm{mmol} / \mathrm{mmol}$

3) $\mathrm{DCAB}=$ high DCAB vs low DCAB

4) $\mathrm{P}<0.05 *, \mathrm{P}<0.01 * *, \mathrm{P}<0.001 * * *$

5) These peripartum means were based on nine rather than ten observations and the sem given should be multiplied by 1.061 when making comparisons with other values.

On the basis of a preliminary analysis the intention was to set the level of the low DCAB diet to about $-50 \mathrm{mEq} / \mathrm{kg}$ DM. Due to a higher content of $\mathrm{K}$ in the diet than expected, the DCAB was found to be more positive than predicted $(+81 \mathrm{mEq} / \mathrm{kg} \mathrm{DM})$. Thus, in practice it could be difficult to accurately formulate DCAB for a grass silage based diet even though the mineral content of feeds is known. In a previous study (Tauriainen et al. 1998a) a DCAB as low as $247 \mathrm{mEq} / \mathrm{kg}$ DM induced metabolic acidosis. Despite the low DCAB the ration with anionic salts was about 3 Eq per day. However, although the daily allowance of anion salts as equivalents was nearly the same in the present study the DCAB was much higher. The $+81 \mathrm{mEq} / \mathrm{kg} \mathrm{DM}$ did not influence either cow acid base balance or some minerals $(\mathrm{Na}, \mathrm{K}, \mathrm{Cl})$ in the plasma or urine which are important electrolytes in body fluid closely linked to the regulation of acid-base balance (Carlson 1989). Thus, the DCAB seems to be a more important factor than the absolute amount of anionic salts. However, three equivalents of anionic salts daily or above is not recommended. Furthermore, it could be necessary to reduce forages that are high in $\mathrm{K}$ in the diet if 
Tauriainen, S. et al. Effect of anionic salts on dry cows III

low DCAB is difficult to achieve on grass silage based diets.

Addition of anionic salts did not reduce dry matter intake (DMI) of the concentrate mixture or hay in the present study. Due to variations in the quality of grass silage, it was sometimes refused by the experimental cows. Concerning concentrate mixture palatability, our results are more promising than Oetzel et al. (1993) reported. Namely when fed various anionic salts, DMI of the concentrate mixture was reduced by $48 \%$ of the amount offered. Additionally in a previous study (Tauriainen et al. 1998a) the palatability of the concentrate mixture was not satisfactory, and therefore the proportion of molasses was increased from $11 \%$ to $16 \%$ of the DM in the present study. Therefore, the palatability of the concentrate mixture would now be acceptable for commercial daily applications. In future it would be useful to replace molasses from sugarbeet with molasses from wheat to minimise the $\mathrm{K}$ content of concentrate mixture.

In the present study $\mathrm{Ca}^{2+}$ concentration in the blood tended to be higher when the DCAB was $+81 \mathrm{mEq} / \mathrm{kg}$ DM in comparison with $+410 \mathrm{mEq} /$ $\mathrm{kg}$ DM. This is in agreement with a previous experiment where a positive DCAB was also used (Tauriainen et al. 1998b). However, although an increase in urinary $\mathrm{Ca}$ excretion and a decrease in urinary $\mathrm{pH}$ were observed, the DCAB with $+81 \mathrm{mEq} / \mathrm{kg}$ DM is too high to affect acidbase balance and Ca metabolism. According to a previous study (Tucker et al. 1992) DCAB should be lower than $-30 \mathrm{mEq} / \mathrm{kg}$ DM. On the basis of feeding trials by Reinhardt et al. (1988), Olson (1991) calculated that the incidence of milk fever should be close to zero when dietary DCAB is $-1250 \mathrm{mEq}$ per day.
Mg intake was 17 g per day ( $0.2 \%$ of the DM) as is recommended in Finland (Tuori et al. 1995). However, $26 \%$ of the cows had hypomagnesemia at parturition. Only one case was noticed in a previous study (Tauriainen et al. 1998a) when magnesium intake was $0.3 \%$ of DM. According to Braak van de et al. (1987) low dietary magnesium (16.6 g Mg/day) resulted in lower bone calcium resorption rates and a smaller exchangeable calcium pool compared with high dietary magnesium (71.0 g/day) in cows at parturition. In contrast, $\mathrm{Ca}$ and $\mathrm{Mg}$ metabolism are interrelated so that diets containing high $\mathrm{Ca}$ and $\mathrm{K}$ and low $\mathrm{Mg}$ reduce absorption of $\mathrm{Mg}$ (Fredeen 1990). In the present study $\mathrm{Ca}$ intake was $82 \mathrm{~g}$ equivalent to twice requirements. These results are confirmed by previous findings (Tauriainen et al. 1998a and b) that the Finnish recommendation of $17 \mathrm{~g} \mathrm{Mg}$ per day may be too low for pregnant dry cows at least when $\mathrm{Ca}$ intake is high.

Our results showed that it could be difficult to formulate a diet with a negative DCAB, if the $\mathrm{K}$ content of grass silage exceeds $30 \mathrm{~g} / \mathrm{kg} \mathrm{DM}$. The palatability of the concentrate mixture was satisfactory even when it contained $3 \mathrm{Eq}$ of anionic salts in the daily portion. However, DCAB is a more important factor than the amount of salts concerning the beneficial effect on acidbase status and calcium metabolism since these changes were not noticed when the DCAB was $+81 \mathrm{mEq} / \mathrm{kg}$ DM. It would be advantageous to increase $\mathrm{Mg}$ intake above Finnish recommended levels when the Ca content of the diet is high.

Acknowledgements. The authors gratefully acknowledge the excellent technical support of Mr Juha Suomi, Mr Jari Miettinen, Mrs Anne Hannikainen, Mr Seppo Pirttikoski and Mr Kimmo Kytölä. The co-operation of staff at the Department of Animal Science is greatly appreciated. 


\section{References}

Abu Damir, H., Phillippo M., Thorp, B. H., Milne, J. S., Dick, L. \& Nevison, I. M. 1994. Effects of dietary acidity on calcium balance and mobilisation, bone morphology and 1,25 dihydroxyvitamin $D$ in prepartal dairy cows. Research in Veterinary Science 56: 310318.

AOAC 1984. Official methods of analysis. Association of Official Analytical Chemists, Inc. Arlington, Virginia. $1141 \mathrm{p}$.

Braak, A. E. van de, Klooster, A. Th van't \& Malestein A. 1986. Influence of prepartum calcium intake on calcium mobilisation rate around parturition in dairy cows fed at a high prepartum feeding level. Veterinary Quarterly 8: 24-37.

-, Klooster, A. Th van't, Goedegebuure, S. A. \& Faber, J. A. J. 1987. Effects of calcium and magnesium intakes and feeding level during the dry period on bone resorption in dairy cows at parturition. Research in Veterinary Science 43: 7-12.

Carlson, G. P. 1989. Fluid, electrolyte and acid-base balance. In: Kaneko, J. J. (ed). Clinical Biochemistry of Domestic Animals. 4th ed. Academic Press, Inc. San Diego California. p. 543-575.

Fredeen, A. H. 1990. Effects of calcium loss and high dietary calcium and potassium on calcium kinetics and magnesium balance in sheep fed low magnesium diets. Canadian Journal of Animal Science 70: 1109-1117.

MAFF 1975. Energy allowances and feeding systems for ruminants. Ministry of Agriculture, Fisheries and Food. London, HMSO. Technical Bulletin 33. 79 p.

Oetzel, G. R. \& Barmore, J. A. 1993. Intake of a concentrate mixture containing various anionic salts fed to pregnant, nonlactating dairy cows. Journal of Dairy Science 76: 1617-1623.

-, Olson, J. D., Curtis, C. R. \& Fettman, M. J. 1988. Ammonium choride and ammonium sulphate for prevention of parturient paresis in dairy cows. Journal of Dairy Science 71: 3302-3309.

Olson, J. D. 1991. Relationships of nutrition to abomasal displacement and parturient paresis. Bovine Practice 26: 88-91.

Phillippo, M., Reid, G. W. \& Nevison, I. M. 1994. Parturient hypocalcaemia in dairy cows, Effects of dietary acidity on plasma minerals and calciotrophic hormones. Research in Veterinary Science 56: 303-309.

Phillips, G. D. 1970. Plasma standard bicarbonate and chloride concentrations in cattle and sheep. British Veterinary Journal 126: 409-418.

Radostits, O. M., Blood, D. C. \& Gay, C. G. 1994. Veteri- an Medicine. 8th ed. Bailliere Tindal. London. p. 1315, 1319, 1727.

Reinhardt, T. A., Horst, R. L. \& Goff, J. P. 1988. Calcium, phosphorus and magnesium homeostasis in ruminants. Veterinary Clinics of North America: Food Animal Practice 4, 2: 331-350.

Romo, G. A., Kellems, R. O., Powell, K \& Wallentine, M. V. 1991. Some blood minerals and hormones in cows fed variable mineral levels and ionic balance. Journal of Dairy Science 74: 3068-3077.

Samson, B. F., Manston, R. \& Vagg, M. J. 1983. Magnesium and milk fever. Veterinary Record 112: 447-449.

SAS 1985. SAS User's Guide, Statistics. 5th ed. SAS Institute Inc. Cary, NC USA. 956 p.

Tauriainen, S., Sankari, S., Pyörälä, S. \& Syrjälä-Qvist, L. 1998a. Effect of anionic salts in concentrate mixture and calcium intake on some blood and urine minerals, acid-base balance and feed intake of dry pregnant cows on grass silage based feeding. Agricultural and Food Science in Finland 7: 523-533.

-, Sankari, S., Pyörälä, S. \& Syrjälä-Qvist, L. 1998b. Effect of anionic salts in concentrate mixture and magnesium intake on some blood and urine minerals and acid-base balance of dry pregnant cows on grass silage based feeding. Agricultural and Food Science in Finland 7: 535-543.

Tucker, W. B., Hogue, J. F., Adams, G. D., Aslam, M., Shin, I. S. \& Morgan, G. 1992. Influence of dietary cation-anion balance during the dry period on the occurrence of parturient paresis in cows fed excess calcium. Journal of Animal Science 70: 1238-1250.

-, Hogue, J. F., Waterman, D. F., Swenson, T. S., Xin, Z., Hemken, R. W., Jackson, J. A., Adams, G. D., \& Spicer, L. J. 1991. Role of sulfur and chloride in the dietary cation-anion balance equation for lactating dairy cattle. Journal of Animal Science 69: 12051213.

Tuori, M., Kaustell, K., Valaja, J., Aimonen, E., Saarisalo, E. \& Huhtanen, P. 1995. Rehutaulukot ja ruokintasuositukset. Helsinki. 99 p.

Wang, C. \& Beede, D. K. 1992. Effects of ammonium chloride and sulphate on acid-base status and calcium metabolism of dry cows. Journal of Dairy Science 75: 820-828.

Windman, E. E., Jones, G. M., Wagner, P. E., Boman, R. L., Troutt, H. F. Jr \& Lesch, T. N. 1982. A dairy cow body condition scoring system and its relationship to selected production characteristics. Journal of Dairy Science 65: 495-501. 
Tauriainen, S. et al. Effect of anionic salts on dry cows III

\title{
SELOSTUS
}

\section{Kationi-anionitasapaino ummessaolevien lypsylehmien säilörehuruokinnassa kalsiumin saannin ollessa runsas}

\author{
Susanna Tauriainen, Satu Sankari ja Liisa Syrjälä-Qvist \\ Helsingin yliopisto
}

Ummessaolevien lehmien kokeessa arvioitiin kationi-anionitasapainon vaikutusta säilörehuvaltaisella ruokinnalla, kun kalsiumin saanti oli runsasta $(82 \mathrm{~g}$ $\mathrm{Ca} / \mathrm{pv})$. Kationi-anionitasapaino laskettiin $\left[\left(\mathrm{Na}^{+}+\mathrm{K}^{+}\right)\right.$ $\left.-\left(\mathrm{Cl}^{-}+\mathrm{S}^{2-}\right)\right] \mathrm{mEq} / \mathrm{kg}$ kuiva-ainetta (ka). Se oli joko +410 tai $+81 \mathrm{mEq} / \mathrm{kg}$ ka. Kalsiumlisä annettiin kalsiumkarbonaattina. Suoloina käytettiin magnesiumkloridia, ammoniumkloridia ja -sulfaattia. Lehmät saivat säilörehua $(5.2 \mathrm{~kg} \mathrm{ka})$, heinää $(0.8 \mathrm{~kg} \mathrm{ka})$ ja täysrehua $(1.7 \mathrm{~kg} \mathrm{ka})$ neljä viikkoa ennen odotettua poikimista poikimispäivään saakka. Veri- ja virtsanäytteitä otettiin 4, 3, 2 ja 1 viikkoa ennen odotettua poikimista, poikimispäivänä sekä 1 vrk ja 1 viikko poikimisen jälkeen. Tulosten mukaan ummessaolevien lehmien kationi-anionitasapainoa on vaikea säätää negatiiviseksi, kun säilörehun kaliumpitoisuus ylittää $30 \mathrm{~g} / \mathrm{kg} \mathrm{ka} .+81 \mathrm{mEq} / \mathrm{kg}$ ka ei aiheuttanut muutoksia verestä ja virtsasta mitattuihin parametreihin. Ainoastaan kalsiumin eritys virtsaan lisääntyi ja virtsan $\mathrm{pH}$ vähentyi kationi-anionitasapainon ollessa +81 $\mathrm{mEq} / \mathrm{kg}$ ka verrattuna positiivisempaan kationi-anionitasapainoon (+410 mEq/kg ka). Koeväkirehun maittavuus oli tyydyttävä, kun anionisten suolojen määrä oli 3 Eq päivässä. 26\%:lla kokeen lehmistä ilmeni poikimisvuorokautena hypomagnesia, vaikka magnesiumin saanti oli suomalaisten suositusten mukaista (17 g Mg/pv). Näin ollen suomalaista magnesiumsuositusta tulisi lisätä ainakin silloin, kun kalsiumin saanti perusrehuista on runsasta. 